\title{
In vitro antifungal susceptibility of Candida spp. isolates from patients with chronic periodontitis and from control patients
}

\section{Suscetibilidade in vitro aos antifúngicos em cepas de Candida spp. isoladas de pacientes com periodontite crônica e de indivíduos controle}

\author{
Cristiane Yumi Koga Ito* \\ Clélia Aparecida de Paiva Martins** \\ Jussara Cia Sanches Loberto*** \\ Silvana Soléo Ferreira dos Santos*** \\ Antonio Olavo Cardoso Jorge ${ }^{* * * *}$
}

\begin{abstract}
Superinfection by Candida can be refractory to conventional periodontal treatments in specific situations, such as in immunocompromised patients. In these cases, the systemic therapy with antifungal drugs could be indicated. The aim of this study was to analyse antifungal susceptibility of Candida spp. strains isolated from chronic periodontitis patients and from control individuals. A total of 39 C. albicans isolates, 9 C. tropicalis, 2 C. glabrata and 5 Candida spp. from control individuals and 30 C. albicans, 3 C. tropicalis and 2 C. glabrata from periodontitis patients were tested. In the control group, 1 isolate of C. glabrata was resistant to ketoconazole and 1 Candida spp. was resistant to amphotericin B, ketoconazole and miconazole. Among the isolates of periodontitis group, $1(3.33 \%)$ C. albicans isolate was resistant to flucytosine and ketoconazole. According to the obtained results, it could be concluded that fluconazole was the most effective drug against the several Candida species studied. There were not expressive differences in the susceptibility of isolates from periodontitis patients or from control individuals.
\end{abstract}

DESCRIPTORS: Candida; Antifungal agents; Periodontitis.

\begin{abstract}
RESUMO: Em certas situações, tal como em pacientes imunocomprometidos, superinfecção por Candida pode ocorrer e ser refratária ao tratamento periodontal convencional. Nesses casos, a terapia sistêmica com antifúngicos pode ser indicada. O objetivo deste trabalho foi estudar a suscetibilidade aos antifúngicos de cepas de leveduras do gênero Candida isoladas de pacientes com periodontite crônica e de indivíduos controle. Um total de 39 isolados de C. albicans, 9 de C. tropicalis, 2 de C. glabrata e 5 de Candida spp. provenientes de indivíduos controle e 30 de $C$. albicans, 3 de C. tropicalis e 2 de $C$. glabrata de pacientes com periodontite foram testados. No grupo controle, uma amostra de C. glabrata foi resistente ao cetoconazol e uma de Candida spp. mostrou-se resistente a anfotericina B, cetoconazol e miconazol. Dentre as amostras do grupo com periodontite, uma $(3,33 \%)$ amostra de C. albicans foi resistente à 5-fluorocitosina e ao cetoconazol. A partir dos resultados obtidos, concluiu-se que fluconazol foi o fármaco mais eficaz contra as várias espécies de Candida estudadas. Não foram observadas diferenças expressivas na sensibilidade de isolados de pacientes com periodontite e de individuos controle.
\end{abstract}

DESCRITORES: Candida; Antimicóticos; Periodontite.

\section{INTRODUCTION}

Candida genus yeasts are considered superinfecting microorganisms $\mathrm{s}^{1,5}$ and can lead to severe periodontal infections in immunocompromised patients or individuals under antimicrobial therapy for long periods ${ }^{9,22}$. Under specific situations, such as in immunodepressed patients ${ }^{3}$, the superinfection by Candida can be refractory to conventional periodontal treatments. In these cases, the systemic therapy with antifungal drugs could be indicated ${ }^{4}$.

Oral candidosis used to be treated with polyene amphotericin B or nystatin ${ }^{18}$. The discovery of antifungal activity of azolic compounds represented an important advance in the treatment of superficial and systemic fungal infections ${ }^{2,25}$. Imidazolic compounds, such as ketoconazole and

\footnotetext{
* PhD, Professor, Discipline of Microbiology and Immunology, Department of Biosciences and Oral Diagnosis; **MS, Oral Bio-

pathology - School of Dentistry of São José dos Campos, São Paulo State University.

*** PhD, Professors; ****Chairman, Professor - Department of Dentistry, University of Taubaté.
} 
Ito CYK, Martins CAP, Loberto JCS, Santos SSF, Jorge AOC. In vitro antifungal susceptibility of Candida spp. isolates from patients with chronic periodontitis and from control patients. Braz Oral Res 2004;18(1):80-4.

fluconazole, have been successfully used in some clinical conditions ${ }^{2}$. Azolic compounds act on the synthesis of the cell membrane of the fungus ${ }^{21}$. Moreover, they inhibit germ tube formation, reducing the adherence to oral epithelial cells and acrylic surfaces ${ }^{6}$.

The chronic use of azolic compounds in the prevention of systemic mycoses, mainly in HIVinfected patients, lead to the selection of isolates resistant to this therapy ${ }^{17}$. In this way, in vitro susceptibility testing became very important, acting as a guide in the selection and control of the antifungal therapy. For this purpose, the National Committee for Clinical Laboratory Standards - NCCLS (1997) ${ }^{14}$ proposed a reference method antifungal susceptibility testing for yeasts using serial dilutions.

Considering that there is no report on the literature on the susceptibility of Candida strains isolated from periodontitis patients, the aim of this work was to study and compare the antifungal susceptibility of Candida strains isolated from chronic periodontitis patients and control individuals.

\section{MATERIALS AND METHODS}

A total of 39 isolates of $C$. albicans, 9 of $C$. tropicalis, 2 of C. glabrata and 5 of Candida spp. from control individuals were tested for the susceptibility to antifungal drugs. From the periodontitis patients, 30 of C. albicans, 2 of C. tropicalis and 3 of $C$. glabrata were tested. The isolates were previously collected through oral rinses.

Isolates from 65 control individuals, aged between 25 to 55 years old $(34.45 \pm 7.93)$, from the dental clinic of the School of Dentistry of São José dos Campos/São Paulo State University were included in the study. Each patient was examined by just one examiner and those that did not present carious lesions, periodontal disease, had no orthodontic appliances, or total or partial dentures were selected. These patients did not report systemic diseases or use of antibiotics during the six months that preceded the collection of the oral rinses.

Isolates from the chronic periodontitis group were collected from 88 patients aged between 25 to 62 years old $(41.33 \pm 5.54)$ and under treatment at the Department of Periodontology of the University of Taubaté (UNITAU). These patients presented at least two different periodontal pockets with probing depth $>5 \mathrm{~mm}$ and were clinically diagnosed as chronic periodontitis patients.

They were informed about the aim of the re- search and about the oral rinse collection. All the patients signed an authorization letter. This project was submitted to and approved by the Bioethic Committee of the School of Dentistry of São José dos Campos/São Paulo State University, SP, Brazil (Protocol number 72/99-PH/CEP).

The isolates were identified by germ tube test, hyphae/pseudohyphae and chlamydospore formation, and assimilation and fermentation of carbohydrates ${ }^{19,27}$. A total of 39 C. albicans isolates, 9 C. tropicalis, 2 C. glabrata and 5 Candida spp. from control individuals and $30 \mathrm{C}$. albicans, $3 \mathrm{C}$. tropicalis and 2 C. glabrata from periodontitis patients were tested.

Antifungal susceptibility assays were determined by the microbroth dilution method in sterile flat-bottomed, 96-well microplates (Difco, Detroit, USA) as described in NCCLS guidelines for macrobroth susceptibility testing, document M27A (1997) ${ }^{14}$. Briefly, Sabouraud dextrose agar was inoculated with the isolates and the plates were incubated for $48 \mathrm{~h}$ at $37^{\circ} \mathrm{C}$. After this period, five colonies, greater than $1 \mathrm{~mm}$ in diameter, were selected and suspended in sterile saline solution $(\mathrm{NaCl} 0.85 \%)$, obtaining an initial concentration of $1-5 \times 10^{6}$ cells per ml (0.5 McFarland scale). This suspension was diluted 1:2,000 in RPMI 1640 medium (Sigma, St. Louis, MO, USA) buffered to pH 7.0 with $0.165 \mathrm{M}$ morpholinepropanesulfonic acid (MOPS, Sigma, St. Louis, USA), obtaining a final concentration of $0.51 \times 10^{3}$ to $2.5 \times 10^{3}$ cells per $\mathrm{ml}$. The antifungal agents: amphotericin B (Sigma Chemical Company, St. Louis, MO, USA), fluconazole (Galena Química e Farmacêutica, São Paulo, Brazil), miconazole (Galena Química e Farmacêutica, São Paulo, Brazil), ketoconazole (Galena Química e Farmacêutica, São Paulo, Brazil) and 5-flucytosine (Sigma Chemical Company, St. Louis, MO, USA) were used for the susceptibility testing.

Amphotericin B, miconazole and ketoconazole were dissolved in dimethyl sulfoxide (Sigma Chemical Company, St. Louis, MO, USA). The other antifungal agents were dissolved in sterile distilled water. The drugs were prepared at the following concentrations: $320 \mu \mathrm{g} \cdot \mathrm{ml}^{-1}$ for amphotericin B, $1,000 \mu \mathrm{g} \cdot \mathrm{ml}^{-1}$ for flucytosine, 1,250 for $\mu \mathrm{g} \cdot \mathrm{ml}^{-1}$ for fluconazole, $640 \mu \mathrm{g} \cdot \mathrm{ml}^{-1}$ for ketoconazole and $\mathrm{mi}-$ conazole. The solutions were diluted in RPMI medium and final drug concentrations ranged from 4 to $0.02 \mu \mathrm{g} \cdot \mathrm{ml}^{-1}$ for amphotericin $\mathrm{B}$, from 64 to 0.02 $\mu \mathrm{g} \cdot \mathrm{ml}^{-1}$ for ketoconazole, miconazole and flucytosine, and from 128 to $0.02 \mu \mathrm{g} \cdot \mathrm{ml}^{-1}$ to fluconazole. 
Ito CYK, Martins CAP, Loberto JCS, Santos SSF, Jorge AOC. In vitro antifungal susceptibility of Candida spp. isolates from patients with chronic periodontitis and from control patients. Braz Oral Res 2004;18(1):80-4.

After $24 \mathrm{~h}$ of incubation at $37^{\circ} \mathrm{C}$, endpoints were determined visually by comparison with the growth control well.

For the azoles and flucytosine, the MIC (minimal inhibitory concentration) endpoints were defined as the lowest drug concentration which resulted in $80 \%$ inhibition. For amphotericin B, this value was defined as the value in which $100 \%$ inhibition was observed.

The results were expressed as ranges of variation of minimum and maximum MIC values obtained for each Candida species. Also, the values of $\mathrm{MIC}_{50}$ and $\mathrm{MIC}_{90}$ were observed. These values represent the drug concentration that inhibits the growth of $50 \%$ and $90 \%$ of the isolates, respectively. C. parapsilosis ATCC 22019 was used as a reference quality control in all the experiments.

The endpoints for the tested drugs considered for the classification of the isolates as susceptible or resistant followed the values stated by Sutton et al. ${ }^{23}$ and NCCLS ${ }^{14}$ as follows: $<1=\mathrm{S}, \geq 2=\mathrm{R}$ for amphotericin $\mathrm{B}$; $<32=\mathrm{S}, \geq 64=\mathrm{R}$ for fluconazole; $<16=\mathrm{S}, \geq 32=\mathrm{R}$ for flucytosine, $<8=\mathrm{S}, \geq$ $16=\mathrm{R}$ for ketoconazole and $<8=\mathrm{S}, \geq 16=\mathrm{R}$ for miconazole $(\mathrm{S}=$ susceptible, $\mathrm{R}=$ resistant, values in $\mu \mathrm{g} / \mathrm{ml})$.

\section{RESULTS}

The results obtained for the susceptibility testing of Candida isolates to amphotericin B, fluconazole, flucytosine, ketoconazole and miconazole for periodontitis and control groups are presented in Tables 1 and 2 respectively. In these tables, the values are expressed as ranges of minimal inhibitory concentration and $\mathrm{MIC}_{50}$ and $\mathrm{MIC}_{90}$ values.

Considering the MIC ranges obtained, in the control group, one C. glabrata isolate was resistant to ketoconazole and one Candida spp. isolate was resistant to amphotericin B, ketoconazole and miconazole.

Analysing the results obtained for periodontitis group, it could be observed that $1(3.33 \%) C$. albicans isolate was resistant to ketoconazole and flucytosine.

\section{DISCUSSION}

Candida genus yeasts are normally present in oral human microbiota, and are considered the only fungal species resident in the human oral cavity. Their isolation rate varies from 10 to $50 \%$ in the literature, however some authors have reported an isolation rate of $80 \%{ }^{3,10,20}$. In the presence of some factors, an increase in Candida multiplica-
TABLE 1 - Number of isolates $(\mathrm{n}=35)$, ranges $(\mu \mathrm{g} / \mathrm{ml})$ of minimal inhibitory concentration (MIC) values, $\mathrm{MIC}_{50}$ and $\mathrm{MIC}_{90}$ values $(\mu \mathrm{g} / \mathrm{ml})$ obtained for the antifungal susceptibility testing of Candida spp. isolates from periodontitis patients.

\begin{tabular}{l|c|c|c|c}
\hline \multicolumn{1}{c|}{ Isolates } & $\mathrm{n}$ & MIC ranges & $\mathrm{MIC}_{50}$ & $\mathrm{MIC}_{90}$ \\
\hline C. albicans & 30 & \multicolumn{4}{|c}{} \\
\hline Amphotericin B & & $0.02-1$ & 0.16 & 0.25 \\
\hline Fluconazole & & $0.04-32$ & 0.5 & 8 \\
\hline Flucytosine & & $0.08-32$ & 0.16 & 1 \\
\hline Ketoconazole & & $0.02-16$ & 0.08 & 1 \\
\hline Miconazole & & $0.02-8$ & 0.04 & 2 \\
\hline C. tropicalis & 3 & & & \\
\hline Amphotericin B & & $0.04-1$ & 0.25 & 1 \\
\hline Fluconazole & & $0.25-32$ & 2 & 32 \\
\hline Flucytosine & & $0.04-1$ & 0.04 & 1 \\
\hline Ketoconazole & & $0.02-4$ & 0.08 & 8 \\
\hline Miconazole & & $0.04-4$ & 0.16 & 8 \\
\hline C. glabrata & 2 & & & \\
\hline Amphotericin B & & $0.04-0.16$ & 0.04 & 0.16 \\
\hline Fluconazole & & $0.25-4$ & 0.16 & 4 \\
\hline Flucytosine & & $0.08-0.25$ & 0.08 & 0.25 \\
\hline Ketoconazole & & $0.16-1$ & 0.25 & 1 \\
\hline Miconazole & & $0.04-0.16$ & 0.04 & 0.16 \\
\hline \hline
\end{tabular}

tion and tissue invasion can occur ${ }^{8,16}$. The incidence of this infection has increased in the last decades due to the widespread use of antibiotics, antifungal drugs, immunosuppressive drugs and some infectious diseases, such as the ones caused by the HIV .

Amphotericin B decreases adherence of Candida to buccal epithelial cells, and can interfere in the pathogenesis of candidosis ${ }^{6}$. The use of amphotericin B in dentistry is commonly local and indicated in superficial candidosis cases ${ }^{4}$. The systemic use is generally indicated in disseminated cases and associated to high toxicity to the patient, causing mainly kidney disorders ${ }^{13}$. In the present study, all the isolates were susceptible to amphotericin B, in both control and periodontitis groups.

Resistance to fluconazole has been reported by several authors ${ }^{11,12,15,26}$. In the present study, all the $C$. albicans isolates tested were susceptible to this drug. The great advantage of fluconazole is the lower occurrence of side effects in relation to other drugs ${ }^{4}$. 
Ito CYK, Martins CAP, Loberto JCS, Santos SSF, Jorge AOC. In vitro antifungal susceptibility of Candida spp. isolates from patients with chronic periodontitis and from control patients. Braz Oral Res 2004;18(1):80-4.

TABLE 2 - Number of isolates $(\mathrm{n}=55)$, ranges $(\mu \mathrm{g} / \mathrm{ml})$ of minimal inhibitory concentration (MIC) values, $\mathrm{MIC}_{50}$ and $\mathrm{MIC}_{90}$ values $(\mu \mathrm{g} / \mathrm{ml})$ obtained for the antifungal susceptibility testing of Candida spp. isolates from control individuals.

\begin{tabular}{|c|c|c|c|c|}
\hline Isolates & $\mathrm{n}$ & MIC ranges & $\mathrm{MIC}_{50}$ & $\mathrm{MIC}_{90}$ \\
\hline C. albicans & 39 & & & \\
\hline Amphotericin B & & $0.02-1$ & 0.25 & 1 \\
\hline Fluconazole & & $0.08-16$ & 0.5 & 2 \\
\hline Flucytosine & & $0.04-2$ & 0.08 & 1 \\
\hline Ketoconazole & & $0.04-8$ & 0.08 & 1 \\
\hline Miconazole & & $0.02-1$ & 0.04 & 0.5 \\
\hline C. tropicalis & 9 & & & \\
\hline Amphotericin B & & $0.02-0.5$ & 0.08 & 0.5 \\
\hline Fluconazole & & $0.5-16$ & 1 & 16 \\
\hline Flucytosine & & $0.04-1$ & 0.08 & 1 \\
\hline Ketoconazole & & $0.02-8$ & 0.5 & 8 \\
\hline Miconazole & & $0.02-2$ & 0.08 & 2 \\
\hline C. glabrata & 2 & & & \\
\hline Amphotericin B & & $0.25-1$ & 0.25 & 1 \\
\hline Fluconazole & & $0.5-32$ & 0.5 & 32 \\
\hline Flucytosine & & $0.08-1$ & 0.08 & 1 \\
\hline Ketoconazole & & $8-32$ & 8 & 16 \\
\hline Miconazole & & $0.5-2$ & 0.5 & 2 \\
\hline Candida spp. & 5 & & & \\
\hline Amphotericin B & & $0.25-16$ & 0.5 & 1 \\
\hline Fluconazole & & $0.25-1$ & 0.5 & 16 \\
\hline Flucytosine & & $0.5-2$ & 0.25 & 2 \\
\hline Ketoconazole & & $0.16-16$ & 0.16 & 4 \\
\hline Miconazole & & $0.04-16$ & 1 & 16 \\
\hline
\end{tabular}

Ketoconazole has been used in the treatment of superficial infections caused by Candida. Its use in dentistry is usually local due to the systemic side effects, such as toxicity. In this study, $1 \mathrm{C}$. albicans isolate from the periodontitis group and also 1 C. glabrata and 1 Candida spp. from the control group were resistant to ketoconazole. These results suggest that considering the toxicity and the presence of resistant isolates, ketoconazole can

\section{REFERENCES}

1. Arendorf TM, Walker DM. Candida albicans: its association with dentures, plaque and oral mucosa. J DASA 1980;35:563-9.

2. Bodey GP. Azole antifungal agents. Clin Infect Dis not be considered the ideal drug for dental use.

Resistance to flucytosine has been reported as a result of monotherapy with this drug. In systemic infection cases, the combination of flucytosine and amphotericin B is used to avoid the development of resistance ${ }^{24}$. In this study, just one C. albicans isolate from the periodontitis group was resistant to flucytosine, indicating a low incidence of resistance to this drug among the studied strains.

Miconazole is indicated for local use in the treatment of oral candidosis ${ }^{4}$, but has been substituted due to its limited power of action and toxicity $^{2}$. Despite the low efficiency reported in previous studies $^{2}$, in the present study just one Candida spp. isolate was resistant to this drug.

Some Candida spp. isolates from the control group could not be identified by phenotipical characteristics. Thus, it was difficult to discuss the results regarding them, especially considering that one of them was resistant to amphotericin B, ketoconazole and miconazole. The identification by genotypic characteristics through molecular techniques could provide us with more information about these isolates.

The results obtained in this study suggest that fluconazole could be more effective in the treatment of periodontal superinfections by Candida that are refractory to conventional treatments. Studies on the correlation between clinical and in vitro results are essentially necessary.

\section{CONCLUSIONS}

According to the results obtained, it can be concluded that fluconazole was the most effective drug against the tested Candida species. Flucytosine, miconazole and amphotericin B presented similar efficacy. Ketoconazole presented the lowest efficacy among the tested drugs. There were no expressive differences in the susceptibility of isolates from periodontitis patients and control individuals.

\section{ACKNOWLEDGEMENTS}

This study was financially supported by FAPESP (The State of São Paulo Research Foundation - 00/14538).

3. Brawner DL, Cuttler JE. Oral Candida albicans isolates from nonhospitalized normal carriers, immunocompetent hospitalized patients, and immunocompromised patients 
Ito CYK, Martins CAP, Loberto JCS, Santos SSF, Jorge AOC. In vitro antifungal susceptibility of Candida spp. isolates from patients with chronic periodontitis and from control patients. Braz Oral Res 2004;18(1):80-4.

with or without acquired immunodeficiency syndrome. J Clin Microbiol 1989;27:1335-41.

4. Budtz-Jorgensen E, Lombardi T. Antifungal therapy in the oral cavity. Periodontol 2000 1996;10:89-106.

5. Cannon RD, Holmes AR, Mason AB, Monk BC. Oral Candida: clearance, colonization, or candidiasis? J Dent Res 1995;74:1152-61.

6. Ellepola ANB, Samaranayake LP. The effect of limited exposure to antimycotics on the relative cell-surface hydrophobicity and the adhesion of oral Candida albicans to buccal epithelial cells. Arch Oral Biol 1998;43:879-87.

7. Frost GI, Csoka T, Stern R. The hyaluronidases: a chemical, biological and clinical overview. Trends Glycosci Glycolechnol 1996;8:419-34.

8. Ghannoum MA, Abu-Elteen KH. Pathogenicity determinants of Candida. Mycoses 1990;33:265-82.

9. Helovuo H, Hakkarainen K, Paunio K. Changes in the prevalence of subgingival enteric rods, staphylococci and yeasts after treatment with penicillin and erythromycin. Oral Microbiol Immunol 1993;8:75-9.

10. Jorge AOC, Koga CY, Gonçalves RC, Fantinato V, Unterkircher CS. Presença de leveduras do gênero Candida na saliva de pacientes com diferentes fatores predisponentes e de indivíduos controle. Rev Odontol Univ São Paulo 1997;11:279-85.

11. Millon L, Manteaux A, Reboux G, Drobacheff C, Monod $\mathrm{M}$, Barale $\mathrm{T}$, et al. Fluconazole-resistant recurrent oral candidiasis in human immunodeficiency virus-positive patients: persistence of Candida albicans strains with the same genotype. J Clin Microbiol 1994;32:1115-8.

12. Monteil RA, Madinier I, Le Fichoux Y. In vitro antifungal resistance of oral Candida albicans strains in non-AIDS patients. Oral Microbiol Immunol 1997;12:126-8.

13. Murphy JW, Friendman H, Bendinelli M. Fungal infections and immune responses. New York: Plenum Press; 1993.

14. National Committee for Clinical Laboratory Standards. Reference method for broth dilution antifungal suscep- tibility testing of yeasts. Proposed standard M27-P- National Committee for Clinical Laboratory Standards: Villanova, PA; 1997.

15. Newman, SL, Flanigan TP, Fisher A, Rinaldi MG, Stein $\mathrm{M}$, Vigilante K. Clinically significant mucosal candidiasis resistant to fluconazole treatment in patients with AIDS. Clin Infect Dis 1994;19:684-6.

16. Odds FC. Candida and candidosis. London: Baillière Tindall; 1988.

17. Odds FC. Resistance of yeasts to azole: derivative antifungals. J Antimicrob Chemother 1993;39:1696-9.

18. Rex JH, Cooper CK, Merz WG, Calgiani JC, Anaissie EJ. Detection of amphotericin B - resistant Candida isolates in a broth based system. J Antimicrob Chemother 1995;39:906-9.

19. Sandvén P. Laboratory identification and sensitivity testing of yeasts isolates. Acta Odontol Scand 1990;48:2736.

20. Scully C, el-Kabir M, Samaranayake LP. Candida and oral candidosis: a review. Crit Rev Oral Biol Med 1994;5:12557 .

21. Segal E, Baum GL. Pathogenic yeast and yeast infections. Florida: CRC Press; 1994.

22. Slots J, Feik D, Rams TE. Age and sex relationships of superinfecting microorganisms in periodontitis patients. Oral Microbiol Immunol 1990;5:305-8.

23. Sutton PA, Fothergill AM, Rinaldi MG. Clinically significant fungi. Baltimore: William \& Wilkins; 1998.

24. Vanden Bossche H, Dromer F, Improvisi I, Lozano-Chiu M, Rex JH, Sanglard D. Antifungal drug resistance in pathogenic fungi. Med Mycol 1998;36(Suppl 1):119-28.

25. Warnock DW. Azole drug resistance in Candida species. J Med Microbiol 1992;37:225-6.

26. White A, Goetz MB. Azole-resistant Candida albicans: report of two cases of resistance to fluconazole and review. Clin Infect Dis 1994;19:687-92.

27. Williams DW, Lewis MAO. Isolation and identification of Candida from the oral cavity. Oral Dis 2000;6:3-11. 